\title{
The Relationship between Sex Chromosomal Chimerism and Vaginal Length in Bovine Heterosexual Twin Females
}

\author{
Yoh-Ichi Miyake, Tsune Ishikawa and Keiichiro KaWata* \\ Department of Veterinary Obstetrics, Faculty of Veterinary Medicine, \\ Hokkaido University, Sapporo 060.
}

\begin{abstract}
Summary. The relationship between the existence of sex chromosomal chimerism in peripheral leucocytes and vaginal length was examined in 33 bovine heterosexual twin females within two weeks after birth. As controls, a pair of twin females and five single-born females of similar age were also examined.

Twenty-four cases of heterosexual twin females with constricted vaginas less than $7.5 \mathrm{~cm}$ in length showed without exception an $\mathrm{XX} / \mathrm{XY}$ chimerism in chromosomal analysis, even though their external genitalia were almost normal in appearance.

However, in the remaining nine heterosexual twin females which had almost normally developed vaginas, 10 to $15 \mathrm{~cm}$ in length; no chimerism was noted in five cases and they produced calves later, while in the remaining four $\mathrm{XX} / \mathrm{XY}$ chimerism was detected.
\end{abstract} In all control cases, no $\mathrm{XX} / \mathrm{XY}$ chimerism was observed.

(Japan. J. Anim. Reprod., 26 9-31, 1980)

\section{Introduction}

It is well known that about $90 \%$ of female partners of heterosexual twins in cattle are congenitally sterile and are called "freemartin", while male ones are fertile (MARCUM, ${ }^{1)}$ '74). OHNo et al. ${ }^{2)}$ ('62), KANAGAWA et al. ${ }^{3,4)}$ ('65a,

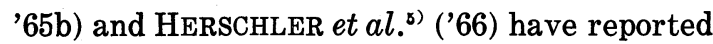
that freemartins and their twin males showed a sex chromosomal chimerism (XX/XY) in cultured peripheral leucocytes and some other tissues, such as lung, gonad, bone marrow, liver and kidney. This is probably due to choriovascular anastomosis during early embryonic stages. However none of the female partners from heterosexual twins or multiples which exhibited estrus or had a calf had an $\mathrm{XX} / \mathrm{XY}$ chimerism. Today, the cytogenetical method clarifying the $\mathrm{XX} / \mathrm{XY}$ chimerism has

* Present address: Department of Veterinary Obstetrics \& Gynecology, School of Veterinary Medicine, College of Dairying, Rakuno Gakuen University, 582 Nishi-Nopporo, Ebetsu, 069-01. widely been used as an early diagnosis of bovine freemartins. In addition, there is a traditional clinical method for diagnosing freemartins based on some characteristic features of the external genitalia and/or vaginal length (SwETt et al., ${ }^{6)}$ ' 40 , Goss, ${ }^{7)}$ '50, Nishimoto et $a l .{ }^{8)}$ '59, ELDRIDGE \& BLAZAK,') '76).

The purpose of the present paper is to examine the relationship between the results of cytogenetical observation and the results of the clinical appearances, particularly the vaginal length, in bovine heterosexual twin females.

\section{Materials \& Methods}

Thirty-three heterosexual twin female Holstein-Friesian calves under two weeks old were examined. A pair of twin females and five single-born females of similar age were also examined as controls.

Clinical examinations were made by observation of the external genitalia, i.e. the size of the clitoris, the length of pubic hairs and the 
Table 1. Comparison of clinical findings and cytogenetical analysis

\begin{tabular}{|c|c|c|c|c|c|}
\hline \multirow{2}{*}{ Group } & \multirow{2}{*}{$\begin{array}{l}\text { Case } \\
\text { No. }\end{array}$} & \multicolumn{2}{|l|}{ Clinical } & \multicolumn{2}{|c|}{ Cytogenetical } \\
\hline & & External genitalia & Vaginal length & $\mathrm{XX} / \mathrm{XY}$ chimerism & $\mathrm{XX} /(\mathrm{XX}+\mathrm{XY})$ \\
\hline \multirow{2}{*}{\multicolumn{2}{|c|}{$\mathrm{I}-1$}} & \multicolumn{3}{|c|}{$\mathrm{cm}$} & $\%$ \\
\hline & & & $\begin{array}{l}\text { Lack of vagina: } \\
\text { only vestibule }\end{array}$ & + & 64 \\
\hline \multirow{2}{*}{\multicolumn{2}{|c|}{$\mathrm{II}-\begin{array}{r}2 \\
3\end{array} \mid$}} & \multirow{15}{*}{$\begin{array}{l}\text { Long and stiff pubic } \\
\text { hairs, large clitoris }\end{array}$} & 3.8 & + & 47 \\
\hline & & & 4.0 & + & 38 \\
\hline & 4 & & 4.5 & + & 65 \\
\hline & 5 & & 4.8 & + & 72 \\
\hline & 6 & & 5.0 & + & 24 \\
\hline & 7 & & 5.0 & + & 37 \\
\hline & 8 & & 5.0 & + & 57 \\
\hline & 9 & & 5.0 & + & 75 \\
\hline & 10 & & 5.4 & + & 42 \\
\hline & 11 & & 5.5 & + & 63 \\
\hline & 12 & & 6.0 & + & 83 \\
\hline & 13 & & 6.5 & + & 28 \\
\hline & 14 & & 6.5 & + & 32 \\
\hline & 15 & & 7.0 & + & 48 \\
\hline & $16 /$ & & 7.5 & + & 67 \\
\hline \multicolumn{2}{|c|}{ III- 17 ) } & \multirow{8}{*}{ Normal-like appearance } & 4.0 & + & 26 \\
\hline & 18 & & 5.0 & + & 73 \\
\hline & 19 & & 5.5 & + & 58 \\
\hline & 20 & & 5.5 & + & 67 \\
\hline & 21 & & 6.0 & + & 48 \\
\hline & 22 & & 6.0 & + & 50 \\
\hline & 23 & & 7.0 & + & 50 \\
\hline & $24)$ & & 7.0 & + & 63 \\
\hline \multicolumn{2}{|c|}{ IV -25 ) } & \multirow{3}{*}{$\begin{array}{l}\text { Few long public hairs } \\
\text { Long pubic hairs, } \\
\text { large clitoris, narrow }\end{array}$} & 10.0 & - & 100 \\
\hline & $26\}$ & & 15.0 & + & 55 \\
\hline & $27)$ & & ragina & + & 83 \\
\hline \multicolumn{2}{|c|}{$\mathrm{V}-28$} & \multirow{6}{*}{ Normal-like appearance } & 10.0 & + & 24 \\
\hline & 29 & & 12.0 & + & 56 \\
\hline & 30 & & 12.0 & - & 100 \\
\hline & 31 & & 14.0 & - & 100 \\
\hline & 32 & & 15.0 & - & 100 \\
\hline & $33)$ & & 15.0 & - & 100 \\
\hline \multicolumn{2}{|c|}{$\mathrm{VI}-34$} & \multirow{7}{*}{ Normal appearance } & 11.5 & - & 100 \\
\hline & 35 & & 13.5 & - & 100 \\
\hline & 36 & & 13.9 & - & 100 \\
\hline & $37\}$ & & 14.8 & - & 100 \\
\hline & 38 & & 15.0 & - & 100 \\
\hline & 39 & & 15.0 & - & 100 \\
\hline & 40 & & 16.5 & - & 100 \\
\hline
\end{tabular}

Notes: Group I-V; Female calves co-twined with a male

Group VI; Nos. 34 \& 35 are homosexual twin females. Nos. $36-40$ are single-born females + ; chimerism, -; non-chimerism 
length of the vagina. For the measurement of the vaginal length, a clinical thermometer $(12.0 \times 0.6 \mathrm{~cm})$ or a glass rod of the pencil size $(20.0 \times 0.5 \mathrm{~cm})$ was correctly inserted into the vaginal cavity avoiding the false insertion into the urethral orifice or suburethral diverticulum and the insertion length from the vulva to the vaginal fornix was measured.

For the cytogenetical examination, leucocytes of peripheral blood were cultured and analyzed chromosomally in the usual manner for the detection of sex chromosomal chimerism (KANAGAWA et $a l$. , $^{4}$ '65b). More than 50 metaphase plates were examined and the ratio of $60, \mathrm{XX}$ cells agaist the total metaphases counted was expressed as the XX percentage. In individual heterosexual twins suspected of having no 60 , XY cells, more than 100 metaphases were examined in order to confirm the non-existence of the XY cells.

As these heterosexual twin female calves were generally sold out, their internal genitalia could not be examined. However, five cases without sex chromosomal chimerism and seven cases of control were not sold and therefore reproductive records of these females was able to be examined later.

\section{Results}

A comparison of the clinical observations and cytogenetical analyses of heterosexual twin females is shown in Table 1. They were categorized into Groups $\mathrm{I}-\mathrm{V}$ according to features of the external genitalia and vaginal length.

In Group I, only one case had long and stiff pubic hairs, a large clitoris and no vagina (the vestibule only).

In Group II, characteristics of the pubic hairs and clitoris were similar to those in Group I, and the vaginal development was highly arrested (vaginal length: $3.8-7.5 \mathrm{~cm}$ ). There were fifteen calves in this group.

Group III consisted of eight cases in which the external genitalia showed a normal-like appearance, but their vaginas were underdeveloped like those in Group II (vaginal length:

\section{$4.0-7.0 \mathrm{~cm})$.}

In three cases belonging to Group IV, more or less abnormal characteristics were observed in the external genitalia, but vaginal length was almost normal $(10,15$ and $15 \mathrm{~cm}$, respectively). In two of them, however, the vagina was narrow at the vulvo-vaginal fold and this led to some resistance when inserting the glass

Table 2. The breeding records of 5 cases and controls without sex chromosomal chimerism

\begin{tabular}{|c|c|c|c|c|}
\hline Case No. & Birth date & First parturition & Gestation length & Sex of newborn calf \\
\hline 25 & $' 74, \quad 7,28$ & $' 77, \quad 2,12$ & 278 & male \\
\hline 30 & $' 75, \quad 1,23$ & '77, 10,16 & 281 & male \\
\hline 31 & ' $73, \quad 5, \quad 4$ & $' 75, \quad 9,25$ & 280 & female \\
\hline 32 & '74, 1,17 & $' 76, \quad 6,19$ & 283 & female \\
\hline 33 & $' 75, \quad 5, \quad 4$ & $' 78, \quad 4,12$ & 279 & female \\
\hline 34 & $75, \quad 3,10$ & $77,11,20$ & 281 & female \\
\hline 35 & $76, \quad 1, \quad 3$ & '78, $\quad 8, \quad 9$ & 283 & male \\
\hline 36 & $' 73,10,13$ & $' 76, \quad 2, \quad 5$ & 279 & male \\
\hline 37 & '74, 6,10 & '77, 1,18 & 275 & female \\
\hline 38 & $' 75, \quad 5,10$ & $77,11,4$ & 282 & female \\
\hline 39 & $' 73, \quad 9,23$ & $' 76, \quad 3,27$ & 285 & female \\
\hline 40 & '74, $8, \quad 5$ & '77, 2,15 & 283 & male \\
\hline
\end{tabular}


rod through that portion. In the six cases in Group V the external genitalia were almost normal and the vaginal length was also similar to that of normal female calves of similar age (vaginal length: 10-15 cm).

Cytogenetically, all cases of Groups I-III showed, without exception, the $\mathrm{XX} / \mathrm{XY}$ chimerism with a considerably high variation of the XX cell percentage (24-83\%). In Group IV, two calves with abnormal external genitalia and $15 \mathrm{~cm}$ of vaginal length showed chimerism, while the one with a few long pubic hairs and a $10 \mathrm{~cm}$ long vagina had cytogenetically no chimerism. As for Group V, only two cases had the sex chromosomal chimerism. The remaining four cases showed no chimerism. The breeding records of these five non-chimeric calves, one in Group IV and four in Group V, were examined later and they were shown to be normal females because they produced calves (Table 2).

In all cases in Group VI as controls, the external genitalia were normal and the vaginal length ranged from 11.5 to $16.5 \mathrm{~cm}$. Chromosomally, no XY cell was observed in these individuals. They had calves later (Table 2).

\section{Discussion}

It is well known that bovine freemartins are characterized by small external genitalia and longer pubic hairs as compared with normal female calves of similar age. Furthermore, it has been reported that the vaginal length at birth ranges from 7.5 to $10.0 \mathrm{~cm}$ in freemartins, while in normal females ranges from 12.0 to $18.0 \mathrm{~cm}$ (Fincher, ${ }^{10)}$ ' 46 ). Nishimoto et $a l .{ }^{8}$ ) ('59) also reported that the vaginal length was $5.2-7.0 \mathrm{~cm}$ in four freemartins and $13.0 \mathrm{~cm}$ in an exceptional case of a freemartin, whereas the length average $15.4 \pm 1.08 \mathrm{~cm}($ mean $\pm S D)$ in seven normal females. According to
ELDRIDGE \& BLAZAK ${ }^{9)}$ ('76), many freemartin calves have so short a vagina that a $150 \times 18 \mathrm{~mm}$ test tube can be inserted only 5.0 to $6.0 \mathrm{~cm}$. Therefore, measurement of vaginal length will be of considerable value for early clinical diagnosis in most freemartin cases.

More than ten years ago, cytogenetical methods were introduced for the early diagnosis of freemartins (KANAGAWA et al.,, ${ }^{3,4}$ ' $65 \mathrm{a} \&$ '65b, MAKINO et al., ${ }^{11)}$ '65, HeRsCHLER et al., ${ }^{\text {s) }}$ '66, KANAGAWA \& BASRUR, ${ }^{12)}$ '68). According to these investigators, freemartins and their twin males showed, without exception, a sex chromosomal chimerism in peripheral leucocytes, whereas normal females have no such chromosomal abnormalities. Today, the chromosomal analysis of cultured leucocytes has become a more reliable and useful method for the early diagnosis of freemartin than some other diagnostic methods such as skin grafting or sex chromatin tests.

The results of the present paper would suggest that there is a close relationship between the chromosomal analysis and vaginal length in bovine heterosexual twin females. Cases in which the vaginal length is less than about $7.5 \mathrm{~cm}$, Groups I-III, would be highly expected to have sex chromosomal chimerism. However, the heterosexual females with a comparatively developed vagina (more than $10 \mathrm{~cm}$ in vaginal length) exhibited sex chromosomal chimerism. Therefore, in such cases with a similar length of vagina to normal calves, and also in cases having a normally developed but partially constricted vagina, cytogenetical examination will be more helpful for diagnosing freemartins.

Acknowledgment We are grateful to Doctor Hiroshi KANAGAWA for his kind reading of the manuscript. 


\section{References}

1) Marcum, J. B.: Anim. Breed. Abst., 42, 227, 1974.

2) Ohno, S., J. M. Trujillo, C. Stenius, L. C. Christian \& R. L. Teplitz: Cytogenetics, 1, 258, 1962.

3) KanAGaWA, H., K. KaWATA \& T. IshiKaWA: Jap. J. vet. Res., 13, 43, 1965a.

4) Kanagawa, H., J. Muramoto, K. Kawata \& T. IsHIKAWA: Ibid., 13, 33, 1965 b.

5) Herschler, M. S., N.S. FeChHeimer \& L. O. Gilmore: J. Dairy Sci., 49, 113, 1966.

6) Swett, W.W., C.A. Matthews \& R.R. Graves: J. Agr. Res., 61, 587, 1940.

7) Goss, L.W.: N. Amer. Vet., 31, 653, 1950.
8) Nishimoto, Y., M. MiYake, T. KameYA \& K. Tanaka: J. Hokkaido vet. med. Ass., 3, 41, 1959. (in Japanese)

9) Eldridge, F.E. \& W. F. BlaZaK: J. Dairy Sci., 60, 458, 1976.

10) Fincher, M.G.: Trans. Amer. Soc. for Study of Steril., 1, 1946. [Roberts, S.J.: Veterinary Obstetrics and Genital Diseases (Theriogenology). 2ed., p. 86, Edwards Brothers, Inc., Ann Arbor, Michigan, (1971)]

11) Makino, S., J. Muramoto \& T. Ishikawa: Proc. Jap. Acad., 41, 414, 1965.

12) Kanagawa, H. \& P.K. Basrur: Can. J. comp. Med., 32, 583, 1968.

(Received Oct. 18, 1979)

\section{牛の異性双児雌に和ける性染色体キメラと胵長との関係}

\section{三宅陽一・石川 恒・河田䓵一郎*}

(北海道大学獣医学部家畜臨床繁殖学教室 *酪農学園大学酪農学部獣医学科家畜臨床繁殖学教室)

牛のフリーマーチンの臨床的早期診断法の精度を知る 目的で, 末梢血中の白血球細胞の性染色体キメラの有無 と腟の長さ括よび外陰部の形状について比較検討した。 用いた材料は出生後 2 週間以内の 33 例の牛の異性双児 の雌で，同性双児の 1 例和よび 5 例の単胎雌をその対照 群とした。

腔長が $7.5 \mathrm{~cm}$ 以下の異性双児雌の 24 例では, たと
え外陰部の形状が正常に近いものであったとしても，染 色体分析の結果では XX/XY キメラを示すことが認めら れた。しかしながら胵長が $10 \sim 15 \mathrm{~cm}$ の異性双児雌の 9 例のらち 5 例ではキメラが認められず，分婏が確認さ れた。しかし残りの 4 例では XX/XY キメラが認められ た。対照群の胵長は $11.5 \sim 16.5 \mathrm{~cm}$ で, 染色体分析の 結果, $\mathrm{XX} / \mathrm{XY}$ キメラは認められなかった。 